\title{
Construction and Demolition Waste Management (Tehran Case Study)
}

\author{
Babak Rouhi Broujeni \\ Environmental Engineering \\ Science and Research \\ Branch, \\ Islamic Azad University, \\ Tehran, Iran
}

\author{
Ghassem Ali Omrani \\ Tehran University of \\ Medical Science \\ Science and Research \\ Branch, Islamic Azad \\ University, Tehran, Iran
}

\author{
Reza Naghavi \\ Islamic Azad University, \\ Tehran, Iran.
}

\author{
Salar S. Afraseyabi \\ Civil and Environmental \\ Engineering \\ Islamic Azad University, \\ Estahbān, Fars, Iran
}

\begin{abstract}
Increasing building construction raises concerns about construction and demolition (C\&D) waste management. To assess this issue the building components, the collection schemes, their recycling and disposal should be investigated. In order to manage C\&D wastes, paying attention to how this kind of wastes is disposed is imperative for their correct identification. Inattention, lack of organization and proper transport and sanitary disposal of construction and demolition waste lead to problems such as accumulation of construction waste in the streets. However, more than 90 percent of the potential for recycling and re-using as raw materials is provided. Environmental Protection Agency (EPA) has classified $C \& D$ wastes into three categories: non-dangerous waste, hazardous wastes and semi-hazardous wastes. Currently in Tehran, an average of about 50,000 tons per day of construction and demolition wastes are produced from which over 30,000 tons per day are dumped in landfills. According to this research more than $57 \%$ of these wastes are placed in the first category (non-dangerous waste) and have the potential for being recycled and reused. On the other hand, items that are placed in the second category shall be managed based on the existing laws. This article provides some management solutions including proposing methods for collecting and reusing construction waste in accordance with current market needs in Iran.
\end{abstract}

Keywords-construction; demolition; waste; recycling; re-use

\section{INTRODUCTION}

Solid wastes produced by construction and demolition (C\&D) activities, are a significant portion of total municipal solid wastes [1]. In developing countries, population growth, urbanization and rising construction process on one hand, and lack of appropriate space for landfill sites on the other hand, intensify the need of recycling and reusing $C \& D$ wastes management, while, much of the urban fabric of these countries, such as Iran, are old and in need of demolition or renovation. In addition, natural disasters such as floods, earthquakes and hurricanes increase $C \& D$ wastes $[2,3]$. Due to the characteristics of C\&D wastes, separating them from other wastes product (waste products) in a city is a very critical step in waste management [4-6]. From 2000 extensive studies have been done to assess solid waste management technology in order to reduce $\mathrm{C} \& \mathrm{D}$ wastes from civil projects or reuse them in to reduce the consumption of raw materials. In 2002, about 11 million tons of $C \& D$ wastes were produced in the United States [4]. Based on figures, in Tehran about 18,250,000 tons of $C \& D$ wastes are produced annually, which in the absence of this type of waste management, average space for burial is 20768055 cubic meters annually. This study attempts to examine an appropriate situation for managing C\&Ds wastes.

According to the U.S. Environmental Protection Agency C\&D wastes consist of three types of waste: (1) nonhazardous waste; (2) hazardous waste as regulated by the Resource Conservation and Recovery Act (RCRA); and (3) items that contain hazardous components that might be regulated by some states [7]. Most C\&D debris is nonhazardous and is not regulated by EPA. In U.S Under RCRA, however, many states have specific definitions of C\&D debris that effectively determine what materials are allowed to be disposed in nonhazardous waste landfills, C\&D landfills, or incinerators. Table I show some examples of C\&D wastes that may not be considered as hazardous wastes according to EPA's definition [6]. In some countries (such as Iran), hazardous C\&D wastes management task is the responsibility of municipalities [8].

\section{MANAGEMENT STRATEGIES}

\section{A. The proposed method for reusing C\&Ds}

Reusing is the use of an item again after it has been used [9, 10]. This includes conventional reuse where the item is used again for the same function, and creative reuse where it is used for a different function [11]. It prevents the consumption of resources, raw materials, energy and reduce waste production. Table II shows C\&D wastes that are reusable. Bet reuse of these materials is being intact and having an acceptable quality [12-14]. Some C\&D wastes can be used in new construction projects only by imposing certain limitations. These types of C\&D wastes are shown in Table III [12-14]. 
TABLE I. SOME EXAMPLES OF HAZARDOUS C\&DS WASTES

\begin{tabular}{|c|c|c|}
\hline Activity & Wastes Generated & Possible RCRA Waste Codes \\
\hline $\begin{array}{l}\text { Land-Clearing, Wrecking and } \\
\text { Demolition }\end{array}$ & $\begin{array}{l}\text { Ignitable or toxic wreckage and } \\
\text { debris, and lead pipe }\end{array}$ & $\begin{array}{l}\text { D001 (ignitable wreckage and debris), D008 (lead pipe, toxic wreckage and lead- } \\
\text { based paint debris), D009 (mercury-containing fluorescent lamps), D023-D026 } \\
\text { (toxic wreckage and debris containing cresols). }\end{array}$ \\
\hline Heavy Construction & $\begin{array}{l}\text { Asphalt wastes, petroleum distillates, } \\
\text { and used oil. (Asphalt is widely } \\
\text { recycled.) }\end{array}$ & $\begin{array}{l}\text { D001 (asphalt wastes, petroleum distillates, used oil sent for disposal), D004 } \\
\text { (arsenic), D006-D008 (used oil sent for disposal containing cadmium, chromium, } \\
\text { or lead), D018 (asphalt wastes containing benzene). }\end{array}$ \\
\hline Carpentry and Floor work & $\begin{array}{l}\text { Acetone, adhesives, coatings, } \\
\text { methylene chloride, methyl ethyl } \\
\text { ketone (MEK), methyl treatisobutyl } \\
\text { ketone (MIK), mineral spirits, sol } \\
\text { vents, toluene, treated wood. }\end{array}$ & $\begin{array}{l}\text { D001 (acetone, adhesives, coatings, methylene chloride, MEK, MIK, mineral } \\
\text { spirits, solvents, trichloroethylene, toluene, xylene), D004 (treated wood), D023- } \\
\text { D026, D037 (treated wood), D035 (MEK), D040 (trichloroethylene), F001 or } \\
\text { F002 (trichloroethylene, methylene chloride), F003 (acetone, xylene, MIK), F005 } \\
\text { (toluene, MEK), U002 (unused acetone), U159 (unused MEK), U161 (unused } \\
\text { MIK), U239 (unused xylene), U220 (unused toluene), U080 (unused methylene } \\
\text { chloride). }\end{array}$ \\
\hline Paint Preparation and Painting & $\begin{array}{l}\text { Acetone, chlorobenzene, glazes, } \\
\text { methanol, MEK, methylene chloride, } \\
\text { paint, petroleum distillates, pigments, } \\
\text { solvents, strippingcompounds, } \\
\text { toluene, and wastewater. }\end{array}$ & $\begin{array}{l}\text { D001 (acetone, chlorobenzene, glazes, methanol, MEK, methylene chloride, } \\
\text { paint, petroleum distillates, solvents, stripping compounds, toluene, wastewater), } \\
\text { D007 (chromium pigments), D008 (lead pigments), D021 (chlorobenzene), D035 } \\
\text { (MEK), F001 and F002 (chlorobenzene), F003 (acetone, methanol), F005 (MEK, } \\
\text { toluene), U002 (unused acetone), U037 (unused chlorobenzene), U159 (unused } \\
\text { MEK), U220 (unused toluene). }\end{array}$ \\
\hline Specialty Contracting Activities & $\begin{array}{l}\text { Acetone, adhesives, coatings, } \\
\text { hexachloroethane, kerosene, MEK, } \\
\text { MIK, pigments, solvents, toluene, } \\
\text { wastewater, and xylene. }\end{array}$ & $\begin{array}{l}\text { D001 (acetone, adhesives, coatings, MEK, MIK, kerosene, solvents, toluene, } \\
\text { wastewater, xylene), D007 (chromium pigments), D008 (lead pigments), D034 } \\
\text { (hexachloroethane), D035 (MEK), F003 (acetone, MIK, xylene), F005 (toluene, } \\
\text { MEK), U002 (unused acetone), U131 (unused hexachloroethane), U159 (unused } \\
\text { MEK), U161 (unused MIK), U220 (unused toluene), U239 (unused xylene). }\end{array}$ \\
\hline
\end{tabular}

TABLE II. C\&D WASTES WHICH CAN BE REUSED

\begin{tabular}{|l|}
\hline \multicolumn{1}{|c|}{ C\&Ds } \\
\hline Bricks, clay pipes, clay blocks alone or attached to the cement \\
\hline $\begin{array}{l}\text { Concrete, cement blocks, tiles, stepping stones, concrete pipes, } \\
\text { cement sand mortar }\end{array}$ \\
\hline Metal components and facility parts \\
\hline Aggregates and building stone \\
\hline Parquet and other wood materials \\
\hline
\end{tabular}

\section{B. The proposed method for recycling C\&D wastes}

Currently in Tehran, about 30,000 tons of C\&D wastes are daily produced by the civil project and Table IV shows the components of these $\mathrm{C} \& \mathrm{D}$ wastes. More than $57 \%$ of these $C \& D$ wastes are recycled. About $16.7 \%$ of these $C \& D$ wastes are soil and rubble which are recycled and converted in situ into sand and gravel. Figure 1 shows the percentage curve of materials which are recycled separately.

The main purposes of recycling C\&D wastes are making good materials with cheap price (subject to compliance with the standard), to avoid filling landfills, and reducing environmental impact and job creation. The most useful C\&D waste that is recycling is mixed soil and rubble which can be considered as the main material in many civil projects after recycling. Mixed soil and rubble recycling process is shown in Figure 2. It should be noted that during the recycling process, environmental tips such as not engaging contaminated materials should be considered (Table V).

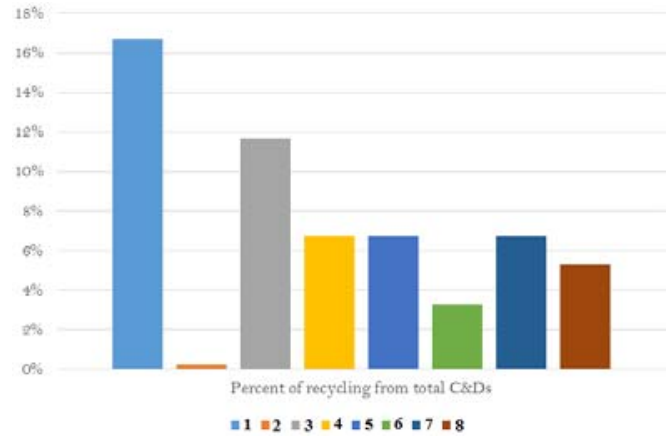

Fig. 1. Percentage of recycled materials (numbers refer to Table IV)

TABLE III. C\&D WASTES WHICH CAN BE REUSED

\begin{tabular}{|l|l|}
\hline C\&Ds & Kind of limitation \\
\hline $\begin{array}{l}\text { Doors, windows } \\
\text { and frames }\end{array}$ & Compliance dimensions \\
\hline Steel profile & $\begin{array}{l}\text { Just can be used in Minor non-structural parts of } \\
\text { buildings. If any features such as corrosion, } \\
\text { deformation and twist not be visible. }\end{array}$ \\
\hline Gravel and sand & Just for floors leveling \\
\hline
\end{tabular}

TABLE IV. RECYCLED PRODUCTS AND RATES

\begin{tabular}{|c|c|c|c|}
\hline & $\begin{array}{c}\text { Recycling } \\
\text { products }\end{array}$ & $\begin{array}{c}\text { The weight of recycled } \\
\text { products (ton) }\end{array}$ & $\begin{array}{c}\text { Percent of recycling from } \\
\text { total C\&Ds }\end{array}$ \\
\hline 1 & $\begin{array}{c}\text { Gravel and } \\
\text { Sand }\end{array}$ & 5000 & 16.7 \\
\hline 2 & Brick & 50 & 0.2 \\
\hline 3 & Ironware & 3500 & 11.7 \\
\hline 4 & Plastics & 2000 & 6.7 \\
\hline 5 & Cardboard & 2000 & 6.7 \\
\hline 6 & Plaster & 1000 & 3.3 \\
\hline 7 & Sack & 2000 & 6.7 \\
\hline 8 & Wood & 1600 & 5.3 \\
\hline
\end{tabular}




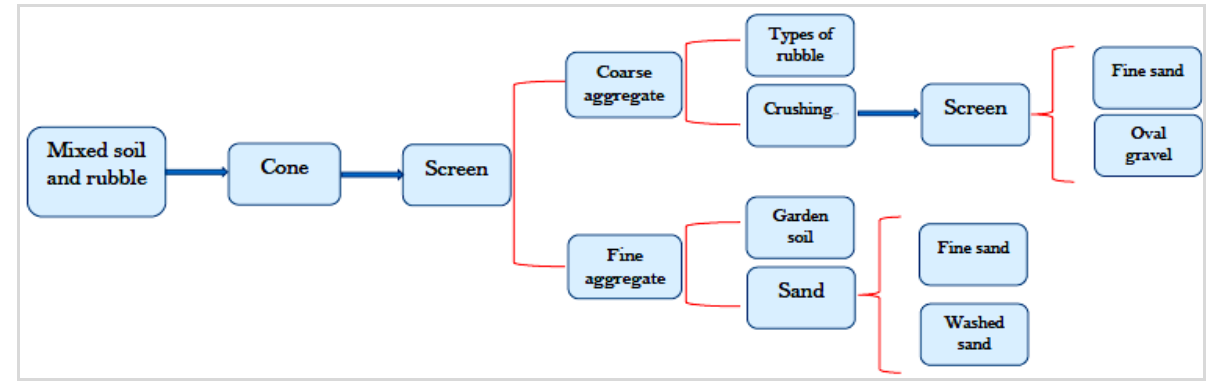

Fig.2. Flowchart of mixed soil and rubble recycling process

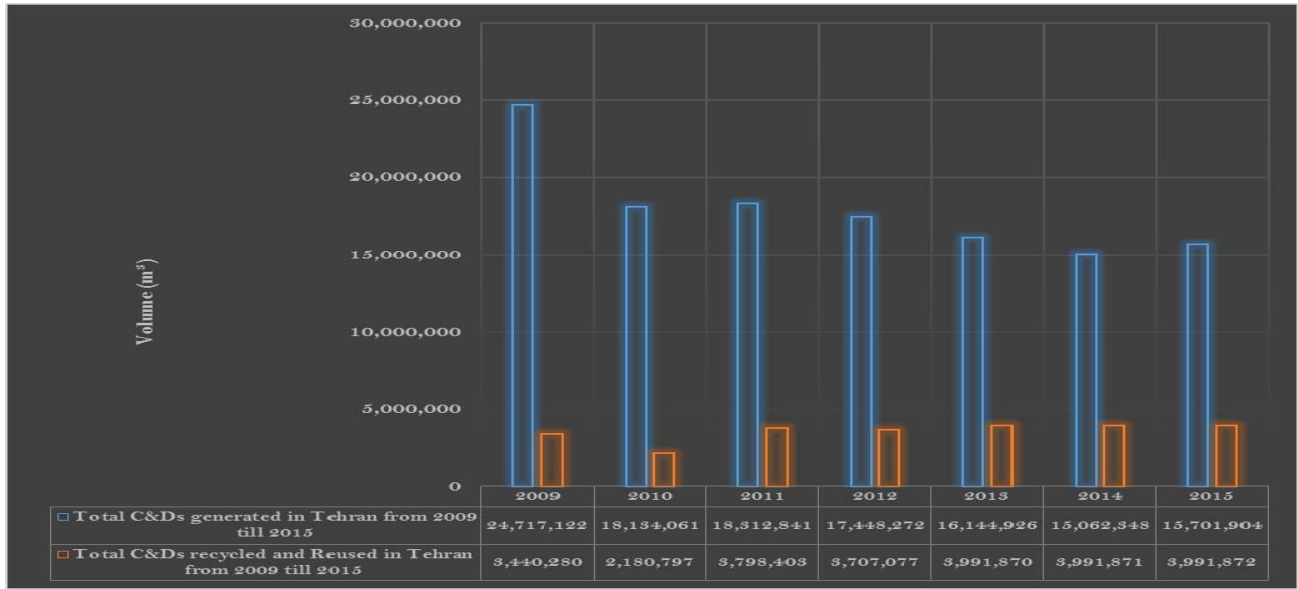

Fig.3. Comparing the amount of left in landfill and C\&D wastes which has been recycled and reused in Tehran.

TABLE V. HOW TO RECYCLE SOLID AND RUBBLE

\begin{tabular}{|l|l|}
\hline \multicolumn{1}{|c|}{ Recycled materials } & \multicolumn{1}{c|}{ How to use } \\
\hline Washed sand with grain size less than $5 \mathrm{~mm}$ & Concrete, foundation \\
\hline Insoles sand & Use as drainage, reinforced concrete columns with low load on \\
\hline Oval gravel from 13 to $25 \mathrm{~mm}$ & Concrete, block and brick construction, foundation \\
\hline Normal gravel 7 to $30 \mathrm{~mm}$ & Concrete, foundation \\
\hline rubble & Parking floor \\
\hline
\end{tabular}

\section{SUGGESTIONS}

To protect the environment against pollution and create safety in construction projects in which the recycled materials are used the following strategies are recommended:

- Selecting and applying appropriate management plans through appropriate tools.

- Making a good market for recycled products.

- Guaranteeing the quality of recycled materials by valid organizations.

In order to reduce the amount of $C \& D$ wastes creation, the following suggestions are intended:

- Correcting storage and use of construction materials.

- Using packaged materials instead of bulk materials.

- Keeping material packages safe till to use.

- Using appropriate Materials with long service life.

\section{CONCLUSION}

The aim of this paper was to show that the existing C\&Ds have good potential for being reused and recycled. Additionally, this research proposes Reuse and recycling of C\&D wastes in order to increase the amount of landfill capacities and reduce the use of raw materials. The way which C\&D wastes can recycle and the way of reuse are proposed also. Statistics show the capability of methods which are used for recycling and reuse of C\&D wastes in this study. Coincided with the rise of recycled and reused C\&D wastes, accumulation of the amounts of $\mathrm{C} \& \mathrm{D}$ wastes in existing landfill has declined.

\section{REFERENCES}

[1] A. Abbas, G. Fathifazl, O. Isgor, A. Razaqpur, B. Fournier, S. Foo "Environmental benefits of green concrete", IEEE Climate Change Technology Conference, pp. 1-8, 2006

[2] M. Osmani, "Construction waste minimization in the UK: curent pressure for change and approaches", Procedia - Social and Behavioral Sciences,Vol. 40, pp. 37-40, 2012 
[3] J. D. Goedert, P. Meadati, "Integrating construction process documentation into building information modeling", Journal of Construction Engineering and Management, Vol. 134, No. 7, pp. 509516,2008

[4] M. Osmani, G. Glass, A. Proce, "Architect and contractor attitudes towards waste minimisation, waste and resource management", Proceedings of the Institution of Civil Engineers - Waste and Resource Management, Vol. 59, No. 2, pp. 65-72, 2006

[5] P. O. Quantity of Construction and Demolition Waste Collected, https://www.wasterecycling.org

[6] Resource Conservation and Recovery Act of 1976 (RCRA), RCRA Hazardous Waste Resources, Construction, Demolition, And Renovation, www.epa.gov/osw/topics.htm

[7] U. Bogenstatter, "Prediction and optimisation of life-cycle costs in early design", Building Research and Information, Vol. 28, pp. 376-386, 2000

[8] O. Faniran, G. Caban, "Minimising waste on construction project sites", Engineering, Construction and Architectural Management, Vol. 5, No. 2, pp. $182-188,1998$
[9] HM Government, Strategy for sustainable construction, UK, 2008, http://webarchive.nationalarchives.gov.uk/+/http:/www.bis.gov.uk/files/f ile46535.pdf

[10] WRAP, 2007a, "Waste recovery quick win case studies" http://www.wrap.org.uk/construction/construction waste minimisation and_management/wrqw_case_studies.html

[11] WRAP, Designing out waste: a design team guide for buildings, 2009

[12] M. L. Tseng, "An assessment of cause and effect decision making model for firm environmental knowledge management capacities in uncertainty", Environmental Monitoring and Assessment, Vol. 161, pp. 549-564, 2010

[13] M. L. Tseng, "Importance-performance analysis on municipal solid waste management in uncertainty", Environmental Monitoring and Assessment, Vol. 172, No. 1-4, pp.171-187, 2011

[14] J. Holmes, G. Capper, G. Hudson, "21st century health care centres in the United Kingdom", Journal of Facilities Management, Vol. 4, pp. 99109, 2006

[15] C. S. Poon, "Reducing construction waste", Waste Management, Vol. 27, pp. 1715-1716, 2007 